\title{
De novo diagnostics of patients with intellectual disability
}

\author{
Joris A Veltman \\ From Beyond the Genome 2012 \\ Boston, MA, USA. 27-29 September 2012
}

Germline coding de novo mutations (SNVs, indels as well as CNVs) are an important cause of moderate to severe forms of intellectual disability (ID) and associated syndromes. Exome sequencing now allows us to reliably identify these mutations using a single genomic test, and we have recently implemented exome sequencing in the diagnostic follow-up of these patients.

In this presentation, I will first discuss the role of $d e$ novo mutations in genetic disease and the associated risk factors such as local genomic structure and paternal age. Next, I will describe our recent work using a diagnostic family-based exome sequencing approach to test this de novo mutation hypothesis in 100 patients with unexplained ID, as well as targeted follow-up studies of several candidate ID genes in 750 additional patients. A total of 79 unique coding de novo mutations were identified and validated in 52 patients. Damaging de novo $(\mathrm{n}=10)$ as well as X-linked maternally-inherited $(\mathrm{n}=3)$ mutations were detected in known ID genes, resulting in a minimal diagnostic yield of $13 \%$ in this cohort. In addition, potentially causative de novo mutations in novel candidate ID genes were detected in 22 patients. For three of these candidate genes, recurrent de novo mutations were identified in patients with similar phenotypes, confirming that they are true ID genes. To further expand the possibilities of exome sequencing for mutation detection, we have recently implemented automatic $\mathrm{CNV}$ detection on exome data, and compared its performance to that of high-resolution genomic microarrays. This analysis shows that exome sequencing can reliably detect the large majority of pathogenic de novo CNVs, responsible for approximately $15 \%$ of ID.

In conclusion, de novo mutations therefore represent an important cause of ID, and exome sequencing is an effective diagnostic strategy for their detection.

Department of Human Genetics, Radboud University Nijmegen Medical Centre, PO Box 9101, 6500 HB Nijmegen, The Netherlands
Published: 1 October 2012

\section{References}

1. Vissers LELM, de Ligt J, Gilissen C, Janssen I, Steehouwer M, de Vries P, van Lier B, Arts P, Wieskamp N, del Rosario M, van Bon BWM, Hoischen A, de Vries BBA, Brunner HG, Veltman JA: A de novo paradigm for mental retardation. Nat Genet 2010, 42:1109-1112.

2. Hehir-Kwa JY, Rodríguez-Santiago B, Vissers LE, de Leeuw N, Pfundt R, Pérez-Jurado LA, Veltman JA: De novo copy number variants associated to intellectual disability have a paternal origin and age bias. J Med Genet 2011, 48:776-778.

3. Veltman JA, Brunner HG: De novo mutations in human genetic disease. Nat Rev Genet 2012, 13:565-575.

\section{doi:10.1186/1753-6561-6-S6-O9}

Cite this article as: Veltman: De novo diagnostics of patients with intellectual disability. BMC Proceedings 2012 6(Suppl 6):O9.

Submit your next manuscript to BioMed Central and take full advantage of:

- Convenient online submission

- Thorough peer review

- No space constraints or color figure charges

- Immediate publication on acceptance

- Inclusion in PubMed, CAS, Scopus and Google Scholar

- Research which is freely available for redistribution
C Biomed Central

(c) 2012 Veltman; licensee BioMed Central Ltd. This is an Open Access article distributed under the terms of the Creative Commons Attribution License (http://creativecommons.org/licenses/by/2.0), which permits unrestricted use, distribution, and reproduction in any medium, provided the original work is properly cited. 